\title{
Desiccation Periods of Urochloa brizantha 'Piatã' Before Sunflower Sowing
}

\author{
Paulo Roberto Fidelis Giancotti ${ }^{1}$, Mariluce Pascoina Nepomuceno ${ }^{1} \&$ Pedro Luís da Costa Aguiar Alves ${ }^{1}$ \\ ${ }^{1}$ College of Agricultural and Veterinary Sciences, Jaboticabal, São Paulo State, Brazil \\ Correspondence: Paulo Roberto Fidelis Giancotti, Faculdade de Ciências Agrárias e Veterinárias (FCAV-UNESP), \\ ZIP code: 14884-900. Jaboticabal, SP, Brazil. Tel: 55-16-3209-2620, ext 218. E-mail: paulogiancotti@gmail.com
}

Received: January 30, 2013 Accepted: March 11, 2013 Online Published: May 15, 2013

doi:10.5539/jas.v5n6p118 URL: http://dx.doi.org/10.5539/jas.v5n6p118

\begin{abstract}
In no-till farming, which integrates crops and livestock, the crop that is sown is often noted for reduced productivity. The aim of this experiment was to study the influence of a desiccation period of Urochloa brizantha 'Piatã' on sunflower 'Aguará 4' development and productivity. The desiccation was carried out using glyphosate herbicide at a dose of $1.92 \mathrm{~kg} \cdot \mathrm{ha}^{-1}$. The treatments consisted of seven periods of $U$. brizantha desiccation (27, 22, 17, 10, 5, 3 and 0 days) prior to sunflower sowing (2010/11). The experimental design established randomized blocks with five replicates. The reduced period between cover desiccation and crop sowing impaired sunflower development (capitulum diameter, plant height, leaf area, and leaf and stem dry masses) over the course of the evaluations, especially for periods less than or equal to 10 days. Thus, our data suggest that sunflower producers should carry out the desiccation at least ten days prior to sowing.
\end{abstract}

Keywords: Brachiaria brizantha, Helianthus annuus, glyphosate, vegetal cover

\section{Introduction}

Crop-livestock integration may consist of crop sowing after pasture desiccation, which is a no-till farming method. The sunflower (Helianthus annuus L.) is a crop that is suited to no-till farming. Researchers have compared sunflower productivity in various cultivation systems and have shown similar levels of production with no-till and conventional-till farming methods (Silva et al., 1997; Anderson et al., 1996).

The species of the genus Urochloa (Syn. Brachiaria) are an efficient cover crop that it is able to fully protect the soil surface (Cobucci, 2001). Urochloa brizantha (Hochst. ex A. Rich.) Stapf cv. Piatã is a great option to use for crop-pasture integration because it displays slower initial growth than other cultivars, a suitable architecture and good mass accumulation during dry periods. Chemical-based pasture control for no-till farming is carried out using non-selective systemic herbicides. Generally, glyphosate is used due to its ability to control pasture growth and its extremely low permanency in the soil (Ashford \& Reeves, 2003).

However, crop sowing on forage may cause injuries and reduced productivity. This reduction may be the result of several factors: the action of allelopathy of the cover crop or, indirectly, the desiccant herbicide (Neumann et al., 2006). The inhibitory effect that cover desiccation provides on the crop that is subsequently sown varies according to the period between pasture desiccation and crop sowing. Regarding the use of $U$. brizantha coverage, more information is needed to clarify the ideal time of desiccation such that crop productivity is not affected (Nunes et al., 2009).

A period of less than 7 days between Urochloa cover desiccation and soybean sowing reduces crop development (Santos et al., 2007; Nunes et al., 2009). However, (Empresa Brasileira de Pesquisa Agropecuária [EMBRAPA], 2006) recommended that the ideal period between pasture desiccation and soybean sowing should be longer: more than 30 days. Therefore, the ideal period for desiccation prior to soybean sowing has already been studied and determined. These results led us to believe that the same effects might occur with other main crops, such as sunflowers.

The aim of this study was to verify the influence of different periods of $U$. brizantha desiccation using glyphosate on sunflower productivity when the seeds were sown using no-till methods. 


\section{Materials and Methods}

The experiment was conducted in 2011 in a soil classified as a Clayey Red Latosol (Oxisol) that had the following chemical properties at $0-20 \mathrm{~cm}$ of depth: $\mathrm{pH}\left(\mathrm{CaCl}_{2}\right) 5.3$; organic matter $23 \mathrm{~g} \cdot \mathrm{dm}^{-3}$; $\mathrm{P}$ (resin) 18 $\mathrm{mg} \cdot \mathrm{dm}^{-3} ; 4.5,34,14,28,52.5$ and $80.5 \mathrm{mmolc} \cdot \mathrm{dm}^{-3}$ of $\mathrm{K}, \mathrm{Ca}, \mathrm{Mg}, \mathrm{H}+\mathrm{Al}$, sum of bases and CEC, respectively; and $70 \%$ base saturation.

The area was laid out in a pasture of established $U$. brizantha cultivar Piatã. The experiment comprised seven periods $(27,22,17,10,5,3$ and 0 days) between herbicide application for $U$. brizantha desiccation and sunflower sowing.

There were five replicates, and the plots were laid out in a randomized block design. The total area per plot was $45 \mathrm{~m}^{2}$, and the net sample area consisted of two rows that were each 10-m long, forming an area of $13.5 \mathrm{~m}^{2}$.

The cover crop was desiccated using glyphosate at a dose of $1.92 \mathrm{~kg}$ of acid equivalent (ae) per ha. The application was performed using a $\mathrm{CO}_{2}$-pressurized backpack sprayer adjusted to spread a volume of $200 \mathrm{~L} \cdot \mathrm{ha}^{-1}$.

A complete NPK (nitrogen, phosphorus and potassium) fertilizer was spread at a rate of $300 \mathrm{~kg} \cdot \mathrm{ha}^{-1}$ (4-14-8 formulation) during the sunflower sowing. It was applied over two split applications. The first application during the sowing spread $300 \mathrm{~kg} \cdot \mathrm{ha}^{-1}$ of NPK (4-14-8 formulation). After 30 days, $90 \mathrm{~kg} \cdot \mathrm{ha}^{-1}$ of urea and $11 \mathrm{~kg} \cdot \mathrm{ha}^{-1} \mathrm{of}$ borax were also applied. Adequate plant protection was provided to guarantee the yield potential.

To control the sunflower caterpillar (Chlosyne lacinia saundersii, Doubleday \& Hewitson), two applications of the mixed insecticide thiamethoxam + lambda-cyhalothrin $[28.2 \mathrm{~mL}+21.2 \mathrm{~mL}$ of active ingredient (ai) per ha] were applied at 30 and 70 days after sowing. To prevent powdery mildew (Erysiphe cichoracearum DC.) infestation, a mix of the two fungicides azoxystrobin + cyproconazole $(40.0 \mathrm{~mL}+16.0 \mathrm{~mL}$ of ai per ha) was applied 60 days after sowing.

The sunflower hybrid Aguará 4, which is characterized by high achene productivity and oil content (45-50\%), was sown on March $17^{\text {th }}$ at the end of the rainy season. The row spacing for the sunflower sowing was $0.9 \mathrm{~m}$, forming a population of 40,000 plants $\cdot \mathrm{ha}^{-1}$.

After three months, an irrigation sprinkler system was installed, and water was applied as necessary to enable achene filling. The pluvial precipitation data are shown in Figure 1. The crop remained in the field for a longer period than necessary to ensure that the capitula sampled were completely dry. Dry capitula are more suited for mechanical threshing.

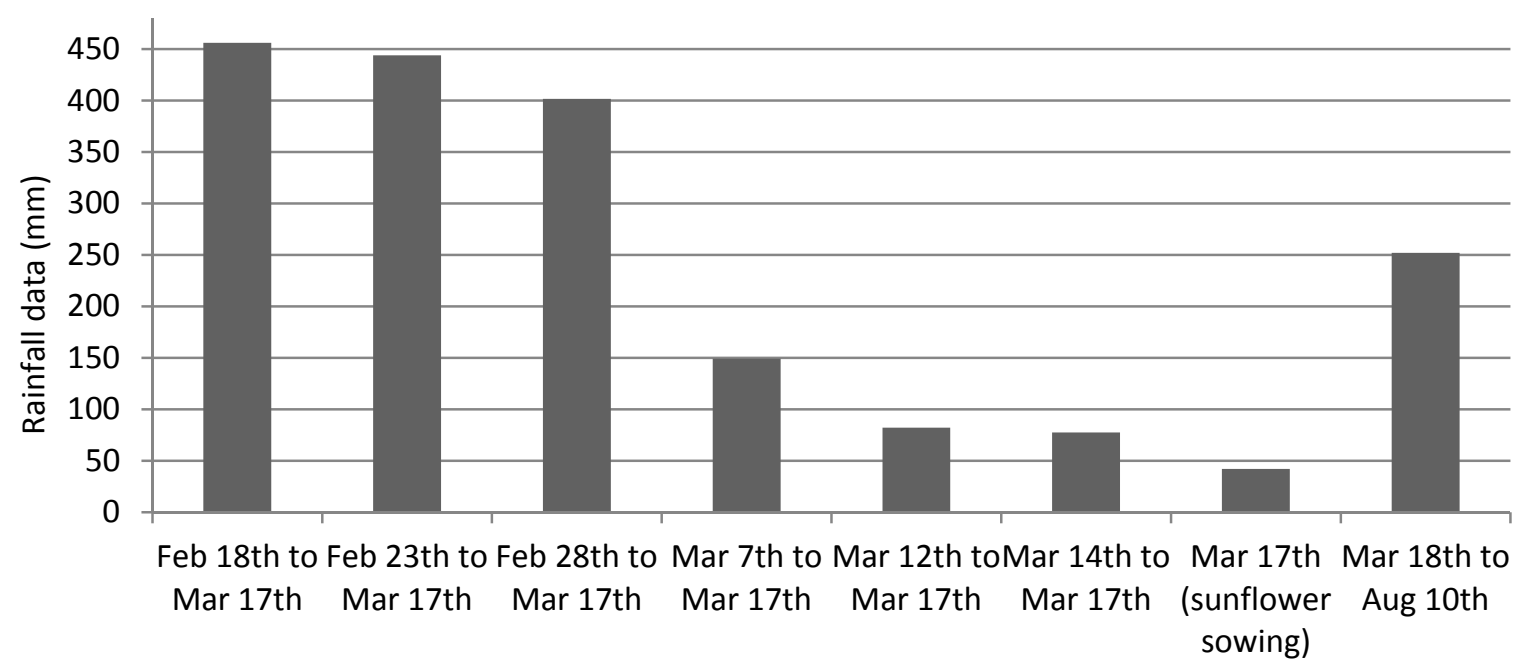

Figure 1. Pluvial precipitation $(\mathrm{mm})$ during the seven periods between cover desiccation and sunflower sowing, on the day of sowing and during the period of crop growth. Source: Agricultural Station,

Department of Exact Sciences of UNESP. Jaboticabal, São Paulo State, Brazil, 2011

A sample area of $0.25 \mathrm{~m}^{2}$ covered by $U$. brizantha was selected for each desiccation time. A sampling frame was thrown randomly into the field four times. The material was cut at the ground level, placed into paper bags and dried with forced air oven at a temperature of $60^{\circ} \mathrm{C}$ until the sample reached a constant dry matter weight. The dry matter weight of the $U$. brizantha cover present in the area was high at $14.8 \mathrm{t}^{-1} \mathrm{ha}^{-1}$ on average. When the 
experiment was installed, the pasture was at a reproductive stage and the vegetative growth had already stabilized. There were no significant variations among the dry matter weights for the different desiccation periods (results not shown). Accordingly, all of the treatments were implemented under the same amount of cover crop matter.

At 45, 90 and 140 days after sowing (DAS), biometric evaluations were performed on the sunflower crop. At 45 DAS, 6 plants per plot were sampled, and for each plant, the heights $(\mathrm{cm})$, numbers of leaves, leaf areas $\left(\mathrm{cm}^{2}\right)$ and dry masses of the stems (g) and leaves (g) were measured. At 90 DAS, the same evaluations were carried out for three plants, and the stem diameter $(\mathrm{mm})$ and capitula diameter $(\mathrm{cm})$ were also evaluated.

At harvest (140 DAS), 20 plants were sampled randomly and the heights, stem diameters and capitula diameters were measured once again. The achene moisture was corrected to $11 \%$ to estimate the yield $\left(\mathrm{kg} \cdot \mathrm{ha}^{-1}\right)$, the dry mass of 100 achenes and the oil content (\%). The oil content was determined by ether extraction, which was conducted at the Laboratory of Animal Nutrition at FCAV/UNESP.

The data obtained were subjected to variance analyses ( $\mathrm{F}$ tests). To compare the means, the data were subjected to the Scott-Knott test at $5 \%$ probability. The data on achene production also underwent regression analyses (OriginPro 8 software) to model how the desiccation effect/sowing affected the achene yield.

\section{Results}

In the first evaluation (at 45 DAS), reduced development of the sunflower plants due to the reduced period between $U$. brizantha desiccation and crop sowing was evident (Table 1). For all of the evaluated parameters, the period of 0 days differed significantly from the others and was always the lowest value. The plants sown after the longest period (27 days after desiccation) had the highest heights, followed by the periods of 22, 17 and 10 days. In the periods between 10 and 27 days, the plants had more leaves and greater leaf areas than the plants sown after shorter desiccation periods. The leaf areas of the plants sown in the periods of 3 and 0 days were reduced to $55 \%$ and $78 \%$, respectively, compared with the longest period. The stem dry mass was also reduced by shorter periods between desiccation and sowing. The periods of 27 and 22 days provided more stem dry mass than 17 and 10 days, followed by the periods of 5 and 3 days.

Table 1. Plant heights $(\mathrm{cm})$, numbers of leaves, leaf areas $\left(\mathrm{cm}^{2}\right)$ and dry masses of leaves $(\mathrm{g})$ and stems $(\mathrm{g})$ of sunflower 'Aguará 4' at 45 days after sowing. The treatments were different time periods between U. brizantha desiccation and no-till sunflower sowing

\begin{tabular}{cccccc}
\hline DAS & Height $(\mathrm{cm})$ & $\begin{array}{c}\text { Number of } \\
\text { leaves }\end{array}$ & Leaf area $\left(\mathrm{cm}^{2}\right)$ & Leaf dry mass $(\mathrm{g})$ & $\begin{array}{c}\text { Stem dry mass } \\
(\mathrm{g})\end{array}$ \\
\hline 27 & $55.37 \mathrm{a}^{1}$ & $16.08 \mathrm{a}$ & $1469.00 \mathrm{a}$ & $6.03 \mathrm{a}$ & $4.95 \mathrm{a}$ \\
22 & $50.83 \mathrm{~b}$ & $16.03 \mathrm{a}$ & $1220.02 \mathrm{~b}$ & $5.14 \mathrm{a}$ & $4.59 \mathrm{a}$ \\
17 & $48.66 \mathrm{~b}$ & $16.13 \mathrm{a}$ & $1216.94 \mathrm{~b}$ & $5.11 \mathrm{a}$ & $3.99 \mathrm{~b}$ \\
10 & $46.43 \mathrm{~b}$ & $15.40 \mathrm{a}$ & $1177.11 \mathrm{~b}$ & $5.05 \mathrm{a}$ & $3.98 \mathrm{~b}$ \\
5 & $42.70 \mathrm{c}$ & $13.83 \mathrm{~b}$ & $831.07 \mathrm{c}$ & $4.05 \mathrm{a}$ & $2.45 \mathrm{c}$ \\
3 & $41.26 \mathrm{c}$ & $13.20 \mathrm{~b}$ & $667.70 \mathrm{c}$ & $2.71 \mathrm{~b}$ & $2.18 \mathrm{c}$ \\
0 & $34.99 \mathrm{~d}$ & $10.78 \mathrm{c}$ & $321.28 \mathrm{~d}$ & $1.28 \mathrm{c}$ & $1.16 \mathrm{~d}$ \\
\hline CV (\%) & 8.17 & 6.68 & 18.37 & 22.71 & 19.43 \\
F (treatments) & $16.25^{*}$ & $21.56^{* *}$ & $24.00^{* *}$ & $15.14^{* *}$ & $23.64^{* *}$ \\
F (blocks) & $0.94^{\mathrm{ns}}$ & $2.89^{*}$ & $4.23^{* *}$ & $2.52^{\mathrm{ns}}$ & $1.63^{\mathrm{ns}}$
\end{tabular}

$*$, **Significant at $\alpha=0.05$ and 0.01 , respectively. ${ }^{\text {ns }}$ not significant. ${ }^{1}$ Within a column, means followed by the same letter are not significantly different according to Scott Knott's F-protected test at $\mathrm{P}=0.05$.

The inhibitory effect provided by reduced periods between $U$. brizantha desiccation and sunflower sowing was in a similar manner at 90 DAS (Table 2). That trend is clearly illustrated by the capitulum dry mass. In the characteristics related to the leaves (leaf area and dry mass), stems (stem diameter and dry mass) and capitulum diameter, there were higher values when the sunflowers were sown in the periods of 27 and 22 days. There was no difference between the treatments with respect to the number of leaves. Only the period of 0 days produced plants that were smaller than for the other periods. 
Table 2. Plant heights $(\mathrm{cm})$, numbers of leaves, stem diameters $(\mathrm{mm})$, capitulum diameters $(\mathrm{cm})$, leaf areas $\left(\mathrm{cm}^{2}\right)$, leaf dry masses $(\mathrm{g})$ and stem dry masses $(\mathrm{g})$ of sunflower 'Aguará 4' 90 days after sowing. The treatments were different time periods between $U$. brizantha desiccation and no-till sunflower sowing

\begin{tabular}{ccccccccc}
\hline DAS & $\begin{array}{c}\text { Height } \\
(\mathrm{cm})\end{array}$ & $\begin{array}{c}\text { Number } \\
\text { of leaves }\end{array}$ & $\begin{array}{c}\text { Stem } \\
\text { diameter } \\
(\mathrm{mm})\end{array}$ & $\begin{array}{c}\text { Capitulum } \\
\text { diameter } \\
(\mathrm{cm})\end{array}$ & $\begin{array}{c}\text { Leaf area } \\
\left(\mathrm{cm}^{2}\right)\end{array}$ & $\begin{array}{c}\text { Leaf dry } \\
\text { mass }(\mathrm{g})\end{array}$ & $\begin{array}{c}\text { Stem dry } \\
\text { mass }(\mathrm{g})\end{array}$ & $\begin{array}{c}\text { Capitulum } \\
\text { dry mass }(\mathrm{g})\end{array}$ \\
\hline 27 & $131.53 \mathrm{a}^{1}$ & $24.57 \mathrm{a}$ & $18.95 \mathrm{a}$ & $14.11 \mathrm{a}$ & $3272.94 \mathrm{a}$ & $22.03 \mathrm{a}$ & $53.50 \mathrm{a}$ & $29.62 \mathrm{a}$ \\
22 & $129.60 \mathrm{a}$ & $24.20 \mathrm{a}$ & $17.99 \mathrm{a}$ & $14.60 \mathrm{a}$ & $3340.20 \mathrm{a}$ & $21.40 \mathrm{a}$ & $55.25 \mathrm{a}$ & $26.06 \mathrm{~b}$ \\
17 & $127.53 \mathrm{a}$ & $23.44 \mathrm{a}$ & $16.77 \mathrm{~b}$ & $12.17 \mathrm{~b}$ & $2517.72 \mathrm{~b}$ & $15.74 \mathrm{~b}$ & $42.31 \mathrm{~b}$ & $18.06 \mathrm{c}$ \\
10 & $127.60 \mathrm{a}$ & $23.00 \mathrm{a}$ & $16.17 \mathrm{~b}$ & $10.36 \mathrm{c}$ & $1793.32 \mathrm{c}$ & $12.88 \mathrm{c}$ & $39.61 \mathrm{~b}$ & $14.87 \mathrm{~d}$ \\
5 & $121.53 \mathrm{a}$ & $23.08 \mathrm{a}$ & $14.99 \mathrm{c}$ & $10.06 \mathrm{c}$ & $1841.86 \mathrm{c}$ & $10.98 \mathrm{~d}$ & $33.90 \mathrm{c}$ & $12.79 \mathrm{e}$ \\
3 & $118.50 \mathrm{a}$ & $22.87 \mathrm{a}$ & $14.68 \mathrm{c}$ & $8.85 \mathrm{c}$ & $1550.47 \mathrm{c}$ & $9.39 \mathrm{e}$ & $29.16 \mathrm{~d}$ & $12.23 \mathrm{e}$ \\
0 & $96.00 \mathrm{~b}$ & $21.17 \mathrm{a}$ & $12.48 \mathrm{~d}$ & $6.71 \mathrm{~d}$ & $1213.50 \mathrm{c}$ & $6.12 \mathrm{f}$ & $18.25 \mathrm{e}$ & $6.84 \mathrm{f}$ \\
\hline CV (\%) & 6.36 & 5.89 & 6.85 & 13.39 & 22.49 & 8.12 & 5.86 & 8.62 \\
F (treats. $)$ & $12.49^{* *}$ & $3.22^{*}$ & $19.67^{* *}$ & $18.61^{* *}$ & $14.19^{* *}$ & $137.76^{* *}$ & $167.07^{* *}$ & $146.70^{* *}$ \\
F (blocks) & $1.26^{\text {ns }}$ & $2.09^{\text {ns }}$ & $5.90^{* *}$ & $2.17^{\text {ns }}$ & $11.01^{* *}$ & $1.83^{\text {ns }}$ & $0.88^{\text {ns }}$ & $1.48^{\text {ns }}$ \\
\hline
\end{tabular}

$*, * *$ Significant at $\alpha=0.05$ and 0.01 , respectively. ${ }^{\text {ns }}$ not significant. ${ }^{1}$ Within a column, means followed by the same letter are not significantly different according to Scott Knott's F-protected test at $\mathrm{P}=0.05$.

At harvest, the parameters analyzed followed the same trends found at earlier developmental stages. As the period between $U$. brizantha desiccation and sunflower sowing decreased, the reductions in the crop productivity characteristics increased (Table 3). The tallest plants were sown during the two longer periods followed by the 17- and 10-day periods. The period of 0 days produced the smallest plants and differed significantly from the other periods. There was no difference between the treatments with respect to the weight of 100 achenes and the oil content. The capitulum diameter only showed a difference compared with the period of 0 days, which produced the lowest value. Although there were no marked differences between the treatments with respect to this characteristic, the low achene production could be explained by the higher number of undeveloped inflorescences.

Table 3. Heights $(\mathrm{cm})$, stem diameters $(\mathrm{mm})$, capitulum diameters $(\mathrm{cm})$, weights of 100 achenes $(\mathrm{g})$, achene production $\left(\mathrm{kg} \cdot \mathrm{ha}^{-1}\right)$ and oil contents (\%) of sunflower 'Aguará 4' at harvest. The treatments were different time periods between $U$. brizantha desiccation and no-till sunflower sowing

\begin{tabular}{ccccccc}
\hline DAS & $\begin{array}{c}\text { Height } \\
(\mathrm{cm})\end{array}$ & $\begin{array}{c}\text { Stem diameter } \\
(\mathrm{mm})\end{array}$ & $\begin{array}{c}\text { Capitulum } \\
\text { diameter }(\mathrm{cm})\end{array}$ & $\begin{array}{c}\text { Weight of } 100 \\
\text { achenes }(\mathrm{g})\end{array}$ & $\begin{array}{c}\text { Achene production } \\
\left(\mathrm{kg} \cdot \mathrm{ha}^{-1}\right)\end{array}$ & $\begin{array}{c}\text { Oil content } \\
(\%)\end{array}$ \\
\hline 27 & $134.86 \mathrm{a}^{1}$ & $17.37 \mathrm{a}$ & $17.77 \mathrm{a}$ & $5.72 \mathrm{a}$ & $1757.31 \mathrm{a}$ & $48.53 \mathrm{a}$ \\
22 & $132.60 \mathrm{a}$ & $17.70 \mathrm{a}$ & $16.42 \mathrm{a}$ & $5.51 \mathrm{a}$ & $1641.94 \mathrm{a}$ & $47.95 \mathrm{a}$ \\
17 & $128.52 \mathrm{~b}$ & $16.54 \mathrm{a}$ & $16.05 \mathrm{a}$ & $5.42 \mathrm{a}$ & $1556.21 \mathrm{a}$ & $49.41 \mathrm{a}$ \\
10 & $127.78 \mathrm{~b}$ & $15.73 \mathrm{~b}$ & $14.80 \mathrm{a}$ & $5.17 \mathrm{a}$ & $1308.35 \mathrm{~b}$ & $48.67 \mathrm{a}$ \\
5 & $120.80 \mathrm{c}$ & $15.04 \mathrm{~b}$ & $15.38 \mathrm{a}$ & $5.11 \mathrm{a}$ & $1295.41 \mathrm{~b}$ & $48.03 \mathrm{a}$ \\
3 & $119.02 \mathrm{c}$ & $15.01 \mathrm{~b}$ & $15.23 \mathrm{a}$ & $5.13 \mathrm{a}$ & $1112.11 \mathrm{~b}$ & $48.51 \mathrm{a}$ \\
0 & $106.00 \mathrm{~d}$ & $13.22 \mathrm{c}$ & $12.49 \mathrm{~b}$ & $4.75 \mathrm{a}$ & $782.41 \mathrm{c}$ & $48.47 \mathrm{a}$ \\
\hline CV (\%) & 3.68 & 5.21 & 9.55 & 9.21 & 18.85 & 2.65 \\
F (treats.) & $23.40^{* *}$ & $17.82^{* *}$ & $6.09^{* *}$ & $2.14^{\text {ns }}$ & $8.71^{* *}$ & $0.42^{\text {ns }}$ \\
F (blocks) & $1.20^{\text {ns }}$ & $4.01^{\text {ns }}$ & $0.51^{\text {ns }}$ & $0.20^{\text {ns }}$ & $1.36^{\text {ns }}$ & $2.78^{\text {ns }}$ \\
\hline
\end{tabular}

**Significant at $\alpha=0.01$. ${ }^{\text {ns }}$ not significant. ${ }^{1}$ Within a column, means followed by the same letter are not significantly different according to Scott Knott's F-protected test at $\mathrm{P}=0.05$.

The variables achene production and stem diameter responded to the periods of pasture desiccation in a similar manner: these variables increased with longer desiccation periods (27, 22 and 17 days) followed by the shorter desiccation periods (10, 5 and 3 days), which differed significantly from 0 days of desiccation. Desiccation on the 
same day as sunflower sowing reduced achene production by 55\% compared with the longer periods between desiccation and sowing.

When analyzed quantitatively, the achene production results showed exponential behavior (Figure 2). Shortening the period between $U$. brizantha desiccation and sunflower sowing caused an exponential reduction in achene production. For an acceptable loss of 5\% in sunflower productivity, $U$. brizantha desiccation must be carried out at least 23 days before no-till crop sowing.

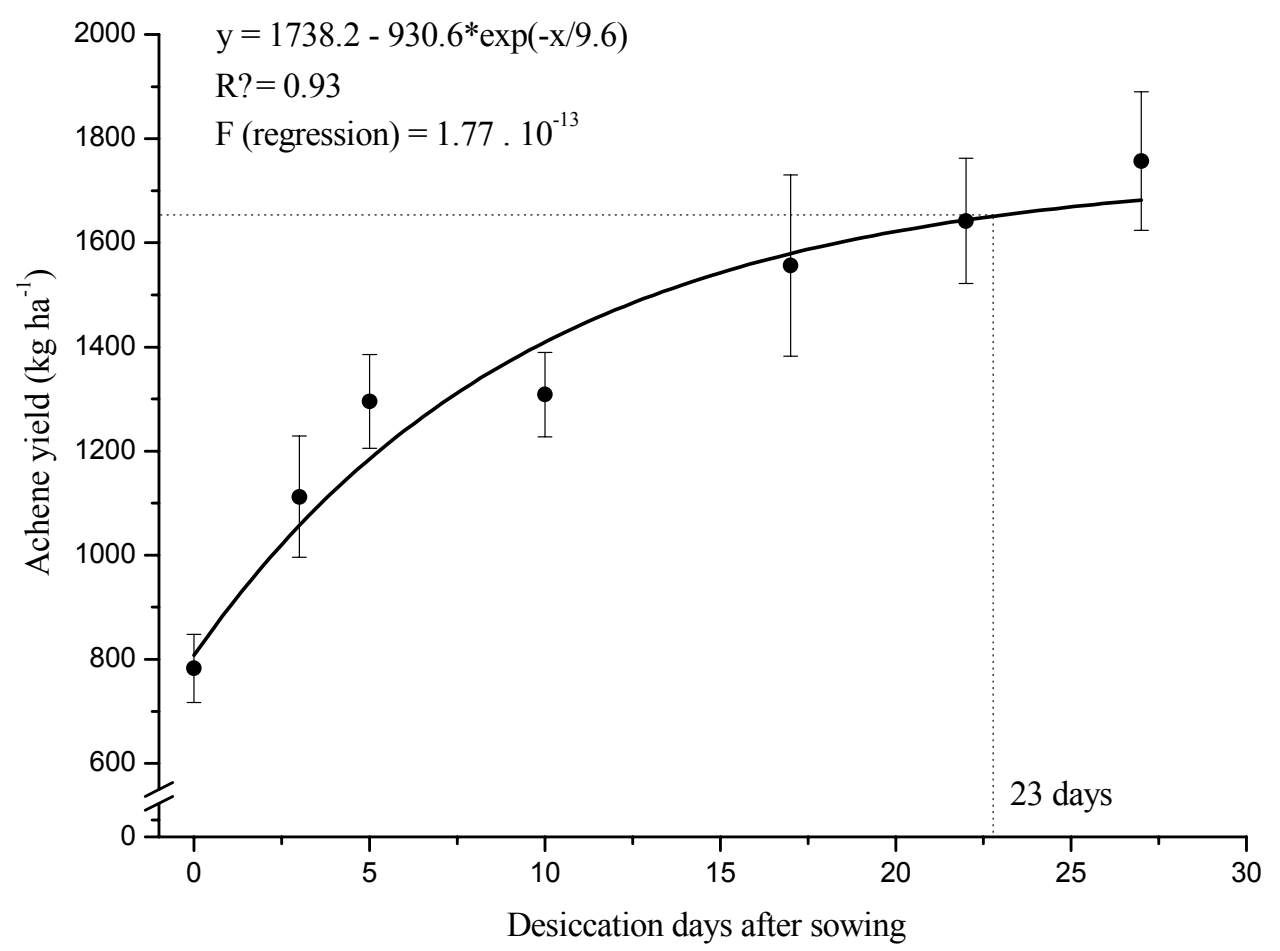

Figure 2. Achene production $\left(\mathrm{kg} \cdot \mathrm{ha}^{-1}\right)$ of sunflower 'Aguará 4' sown at increasing periods after $U$. brizantha desiccation

\section{Discussion}

A period equal to or longer than 17 days showed higher crop productivity. This period was similar to the period proposed by Silva (2001) for no-till corn but differed from the period of Nunes et al. (2009) and Nepomuceno et al. (2012) for soybean sowing. However, previous studies documented productivity reductions when the sowing was carried out on the same day as the desiccation. In this study, the productivity reduction provided by this treatment was similar to the $50 \%$ reduction observed by Nunes et al. (2009).

Fancelli and Dourado Neto (2004) affirmed that a high production of organic compounds and the permanence of the vegetation cover allowed the expression of allelopathic effects. Martins et al. (2006) showed the allelopathic potential of $U$. brizantha. The compound responsible for this effect has been isolated and is derived from a steroidal saponin called protodiocsin (Nepomuceno, 2011). Considering that the pasture had a high density and that the plants of this genus persisted for a long time (Cobucci, 2001), the release of $U$. brizantha allelochemicals may have caused negative effects on the sunflowers. The release of allelopathic compounds can occur during the decomposition of the plant tissues (Macías et al., 2007). Assuming that the decomposition of the dense cover was slow, this gradual release could explain the damage observed even 10 days after desiccation.

The high glyphosate dose used for $U$. brizantha desiccation could also be the cause of the reduction in sunflower development and productivity when sown at shorter periods after desiccation. Furthermore, the slow decomposition of the dense cover after treatment could prolong the phytotoxic effect of the glyphosate that is released during this process (Neumann et al., 2006; Tesfamariam et al., 2009). Due to the low Kow of glyphosate (Battaglin et al., 2005) and the heavy rains in the days after desiccation, the glyphosate was potentially released 
from the vegetal residue and then became available for absorption by the sunflower seedlings.

Although nutritional features were not analyzed in this experiment, nutritional deficiencies may also have occurred in this experiment. Tesfamariam et al. (2009) found manganese nutritional deficiencies in sunflowers even when the sowing occurred longer than 21 days after the pasture desiccation. This potential of the herbicide to cause a nutritional deficiency even when the sowing is carried out many days after desiccation may perhaps explain the productivity reduction found after the 10-day interval in our study.

In addition to the nutritional questions, there is also the problem of the low availability of nitrogen to crops sown on grass. This fact is mainly due microbial immobilization of the nutrient. Although no-till farming methods provide an increase in the total nitrogen content of the soil, lower absorption of nitrogen by crops in this system of farming has frequently been observed.

\section{Conclusion}

U. brizantha desiccation (with a dose of $1.92 \mathrm{~kg}$ of acid equivalent per ha for a dry mass of cover of $14.8 \mathrm{t} \cdot \mathrm{ha}^{-1}$ ) in a period equal to or less than 10 days before no-till sowing of sunflower 'Aguará 4' caused a reduction in crop development and productivity. The period of desiccation influences the sunflower productivity, either by $U$. brizantha allelopathy or by a glyphosate phytotoxic effect. One or both of these factors were responsible for a $50 \%$ reduction in sunflower production when sowing occurred at the same time as $U$. brizantha desiccation. Thus, it is clear that sunflower producers should perform desiccation at least ten days before sowing.

\section{References}

Anderson, R. L., Lyon, D. J., \& Tanaka, D. L. (1996). Weed management strategies for conservation-tillage sunflower (Helianthus annuus). Weed Technology, 10, 55-59.

Ashford, D. L. \& Reeves, D. W. (2003). Use of a mechanical roller-crimper as an alternative kill method for cover crops. American Journal of Alternative Agriculture, 18, 37-45. http://dx.doi.org/10.1079/AJAA200232

Battaglin, W. A., Kolpin, D. W., Scribner, E. A., Kuivila, K. M., \& Sandstrom, M. W. (2005). Glyphosate, other herbicides, and transformation products in midwestern streams, 2002. Journal of the American Water Resources Association, 41, 323-332.

Cobucci, T. (2001). Manejo integrado de plantas daninhas em sistema de plantio direto. In L. Zambolim (Eds.), Manejo integrado fitossanidade: cultivo protegido, pivô central e plantio direto (pp. 583-624). UFV, Viçosa, MG, Brazil.

Empresa Brasileira de Pesquisa Agropecuária [EMBRAPA]. (2006). Tecnologia de produção de soja na Região Central do Brasil 2007. Londrina, PR, Brazil: Embrapa Soja.

Fancelli, A. L., \& Dourado-Neto, D. (2004). Produção de milho. Guaíba, RS, Brazil: Agropecuária.

Macías, F. A., Molinillo, J. M. G., Varela, R. M., \& Galindo, J. C. G. (2007). Allelopathy - a natural alternative for weed control. Pest Management Science, 63, 327-348. http://dx.doi.org/10.1002/ps.1342

Martins, D., Martins, C. C., \& Costa, N. V. (2006). Allelopathic potential of solutions of soils cultivated with Brachiaria brizantha: effects on some pasture grass and weeds seeds. Planta Daninha, 24, 61-70 (in Portuguese, with abstract in English). http://dx.doi.org/10.1590/S0100-83582006000100008

Nepomuceno, M. P. (2011). Burndown interval of Urochloa ruziziensis (R. German \& Evrard) Crins and its allelopatic effect on RR. Thesis. UNESP, São Paulo State University, Jaboticabal, SP, Brazil soybean (in Portuguese, with abstract in English).

Nepomuceno, M. P., Varela, R. M., Alves, P. L. C. A., \& Martins, J. V. F. (2012). Burn-down timing of Urochloa ruziziensis and its effect on RR soybean yield. Planta Daninha, 30, 557-565 (in Portuguese, with abstract in English). http://dx.doi.org/10.1590/S0100-83582012000300011

Neumann, G., Kohls, S., Landsberg, E., Stock-Oliveira Souza, K., Yamada, T., \& Römheld, V. (2006). Relevance of glyphosate transfer to non-target plants via rhizosphere. Journal of Plant Diseases and Protection, 118, 936-969.

Nunes, A. S., Timossi, P. C., Pavani, M. C. M. D., \& Alves, P. L. C. A. (2009). Brachiaria decumbens management times in soybean under no tillage system. Planta Daninha, 27, 297-302 (in Portuguese, with abstract in English). http://dx.doi.org/10.1590/S0100-83582009000200012 
Santos, J. B., Santos, E. A., Fialho, C. M. T., Silva, A. A., \& Freitas, M. A. M. (2007). Influence of desiccation time before sowing on the development of soybean resistant to glyphosate. Planta Daninha, 25, 869-875 (in Portuguese, with abstract in English). http://dx.doi.org/10.1590/S0100-83582007000400024

Silva, P. R. F., Wendt, W., \& Rocha, A. B. (1997). Effect of soil management system and fertilization level on sunflower cultivated after Avena strigosa. Pesquisa agropecuária brasileira, 32, 641-647 (in Portuguese, with abstract in English).

Tesfamariam, T., Bott, S., Cakmak, I., Römheld, V., \& Neumann, G. (2009). Glyphosate in the rhizosphere-Role of waiting times and different glyphosate binding forms in soils for phytoxicity to non-target plants. European Journal Agronomy, 31, 126-132. http://dx.doi.org/10.1016/j.eja.2009.03.007 